\title{
The Time Course of Blood Glucose Metabolism in Response to Acute Cold Exposure in Sheep
}

\author{
Akemi TAKEBAYASHI, Kaoru KOBAYASHI, \\ Tadahisa FUJITA, Hiroaki SANO \\ and Akio SHIGA
}

Faculty of Agriculture, Iwate University, Morioka-shi 020-8550

(Received April 8, 1998)

\begin{abstract}
Four sheep were moved from a thermoneutral environment $\left(20 \pm 1^{\circ} \mathrm{C}\right)$ to a cold environment $\left(1 \pm 1^{\circ} \mathrm{C}\right)$ for 4 hours to determine the time course of changes in production and utilization rates of blood glucose in response to acute cold exposure. An isotope dilution method using $\left[\mathrm{U}^{-13} \mathrm{C}\right]$ glucose and non-steady state equations was applied to determine blood glucose metabolism. Rates of blood glucose production and utilization were relatively constant in the thermoneutral environment at $3.9 \pm 0.2$ and $3.7 \pm 0.3 \mathrm{mg} \cdot \mathrm{kg}^{-0.75} \cdot \mathrm{min}^{-1}$, respectively. Both rates increased associated with the initiation of cold exposure, reaching $6.5 \pm 0.6$ and $6.2 \pm 0.4 \mathrm{mg} \cdot \mathrm{kg}^{-0.75}$. $\mathrm{min}^{-1}$ respectively at $30 \mathrm{~min}(\mathrm{P}<0.01)$, and were maintained at higher levels than in the thermoneutral environment. The results of this experiment suggest that in sheep blood glucose metabolism is enhanced immediately after the initiation of cold exposure.
\end{abstract}

Anim. Sci. Technol. (Jpn.) 69 (8) : 734-740, 1998

Key words : Blood glucose metabolism, Cold exposure, Stable isotope, Sheep

When livestock animals are exposed to a cold environment, they atternpt to maintain their homeothermy by reducing heat loss and enhancing thermogenesis using their neuroendocrine systems ${ }^{8)}$. Cold exposure is one of the factors which can reduce the productivity of livestock animals. Glucose is a significant energy source for ruminants even though they rely on volatile fatty acids as their major energy source. Blood glucose turnover rates are enhanced during cold exposure in sheep, as measured by isotope dilution methods ${ }^{1,11,15,17}$. However, little attention has been paid to changes in blood glucose metabolism associated with the initiation of cold exposure. The objective of the present experiment was to measure the time course of changes in blood glucose metabolism using a stable isotope under non-steady state conditions in sheep exposed from a thermoneutral environment to a cold environment for a short time period. The use of non-steady state equations allowed us to calculate separate rates of blood glucose production and utilization. Moreover, concentrations of some blood metabolites and catecholamines were also determined.

\section{Materials and Methods}

\section{Animals and diets}

Four crossbred (Suffolk $\times$ Corriedale) sheep, three ewes and one ram, aged 2 years and weighing $59 \mathrm{~kg}$ ( 50 to $71 \mathrm{~kg}$ ) of body weight (BW) were used. At least 3 months before the experiment, they were surgically prepared with a skin loop enclosing the left carotid artery under anesthesia induced by intramuscular injection of xylazine $(0.1 \mathrm{mg} / \mathrm{kg}$ BW). The sheep were kept in metabolism cages in a controlled environment chamber at an air temperature of $20 \pm 1^{\circ} \mathrm{C}$. They were fed 
$2 \% \mathrm{BW}$ of alfalfa hay cubes and $0.5 \% \mathrm{BW}$ of commercial concentrate once daily at $18: 00 \mathrm{~h}$. Water was given ad libitum. Animals were shorn and a polyvinyl catheter for infusion was inserted into a jugular vein a day before the experiment. A catheter for blood samplings was inserted into the arterial loop on the morning of experiment. All catheters were filled with a sterile solution of $3.8 \%$ trisodium citrate. The experiment was carried out without noticeable stress to the sheep except for direct responses to cold exposure.

\section{Experimental procedures}

The isotope dilution procedure for determination of production and utilization rates of blood glucose was commenced in the thermoneutral environment. Ten milligrams of [U${ }^{13} \mathrm{C}$ ]glucose (D-glucose $-{ }^{13} \mathrm{C}_{6}, 99$ atom \% excess ${ }^{13} \mathrm{C}$, Isotec Inc., A Matheson, USA Co., USA) dissolved in saline solution were injected into the jugular catheter as a priming dose at 10:00 h. $\left[\mathrm{U}^{-13} \mathrm{C}\right]$ Glucose was then continuously infused by a multichannel peristaltic pump (AC2120 , Atto Co. Ltd., Japan) at a rate of $8 \mu \mathrm{g}$. $\mathrm{kg}^{-0.75} \cdot \mathrm{min}^{-1}$ through the same catheter for 480 min. At 240 min after the initiation of $\left[\mathrm{U}-{ }^{19} \mathrm{C}\right]$ glucose infusion, the sheep's metabolism cages were moved about 10 meters from the chamber controlled at the thermoneutral environment to the cold environment chamber $\left(1 \pm 1^{\circ} \mathrm{C}\right)$, and cold exposure was commenced. Blood samples for determination of blood glucose metabolism were taken from the carotid artery catheter at 0 (immediately before infusion), 180, 210, $240,270,300,330,360,390,420,450$, and $480 \mathrm{~min}$ after the initiation of $\left[\mathrm{U}-{ }^{13} \mathrm{C}\right]$ glucose infusion. Blood samples at 245,250 , and $255 \mathrm{~min}$, corresponding to 5,10 , and $15 \mathrm{~min}$ after the initiation of cold exposure, were also collected. Samples were transferred into centrifuge tubes which contained heparin sodium, and were chilled until centrifugation.

\section{Analyses}

Blood samples were centrifuged at $4,500 \times g$ for $10 \mathrm{~min}$ at $4^{\circ} \mathrm{C}$, and the plasma was stored at $-20^{\circ} \mathrm{C}$ until further analyses. Derivatization of plasma glucose was performed by the procedure of Tserng and Kalhan ${ }^{14)}$ with slight modifications after isolation from plasma with ion exchange resin ${ }^{3}$. Concentrations of glucose were determined by an automated glucose analyzer (GLU-1, Erma Optical Works, Japan). Concentrations of free fatty acids (FFA) were determined with a kit (NEFA C test, Wako Pure Chemicals, Japan). Lactate was determined by the method described by Taylor ${ }^{12}$. Catecholamines were determined by high performance liquid chromatography (HL 8030, Toso Co. Ltd., Japan). Concentrations of plasma catecholamines were determined for the samples taken immediately before and at $30,60,120$, and $240 \mathrm{~min}$ after the initiation of cold exposure.

\section{Calculations}

Mean values with standard errors (SE) are given. The production and utilization rates of blood glucose ( $\mathrm{Rp}$ and $\mathrm{Ru}$, respectively) were calculated by the equations described by Sano et $a l^{6}{ }^{6}$, based on the non-steady state equations proposed by Steele ${ }^{10)}$.

$$
\begin{aligned}
\mathrm{Rp}= & \left(\mathrm{I}-p * \mathrm{~V} *\left(\left(\mathrm{C}_{2}+\mathrm{C}_{1}\right) / 2\right) *\left(\left(\mathrm{E}_{2}-\mathrm{E}_{1}\right) /\right.\right. \\
& \left.\left.\left(\mathrm{t}_{2}-\mathrm{t}_{1}\right)\right)\right) *\left(100 /\left(\mathrm{E}_{2}+\mathrm{E}_{1}\right) * 2-1\right) \\
\mathrm{Ru}= & \mathrm{Rp}-p * \mathrm{~V} *\left(\left(\mathrm{C}_{2}-\mathrm{C}_{1}\right) /\left(\mathrm{t}_{2}-\mathrm{t}_{1}\right)\right)
\end{aligned}
$$

where $\mathrm{I}$ is $\left[\mathrm{U}^{-13} \mathrm{C}\right]$ glucose infusion rate, $\mathrm{C}_{1}$ and $\mathrm{C}_{2}$ are blood glucose concentrations, $\mathrm{E}_{1}$ and $\mathrm{E}_{2}$ are the enrichments of plasma $\left[\mathrm{U}^{-13} \mathrm{C}\right]$ glucose $(\%)$ at times $t_{1}$ and $t_{2}$, respectively. $\mathrm{V}$ is the glucose distribution volume and $p$ is the pool fraction. The glucose distribution volume and the pool fraction were assumed to be 179 $\mathrm{m} l / \mathrm{kg} \mathrm{BW}$ in the thermoneutral environment and $218 \mathrm{ml} / \mathrm{kg} \mathrm{BW}$ during cold exposure, and 0.85 , respectively ${ }^{6,17)}$. Data were analyzed with the General Linear Model procedure of the Statistical Analysis System ${ }^{7}$. Student $t$-tests were used to compare the least squares means for the thermoneutral environment and after the initiation of cold exposure. Results were considered significant at the $\mathrm{P}<0.05$ level. 


\section{Results}

In the thermoneutral environment, the mean
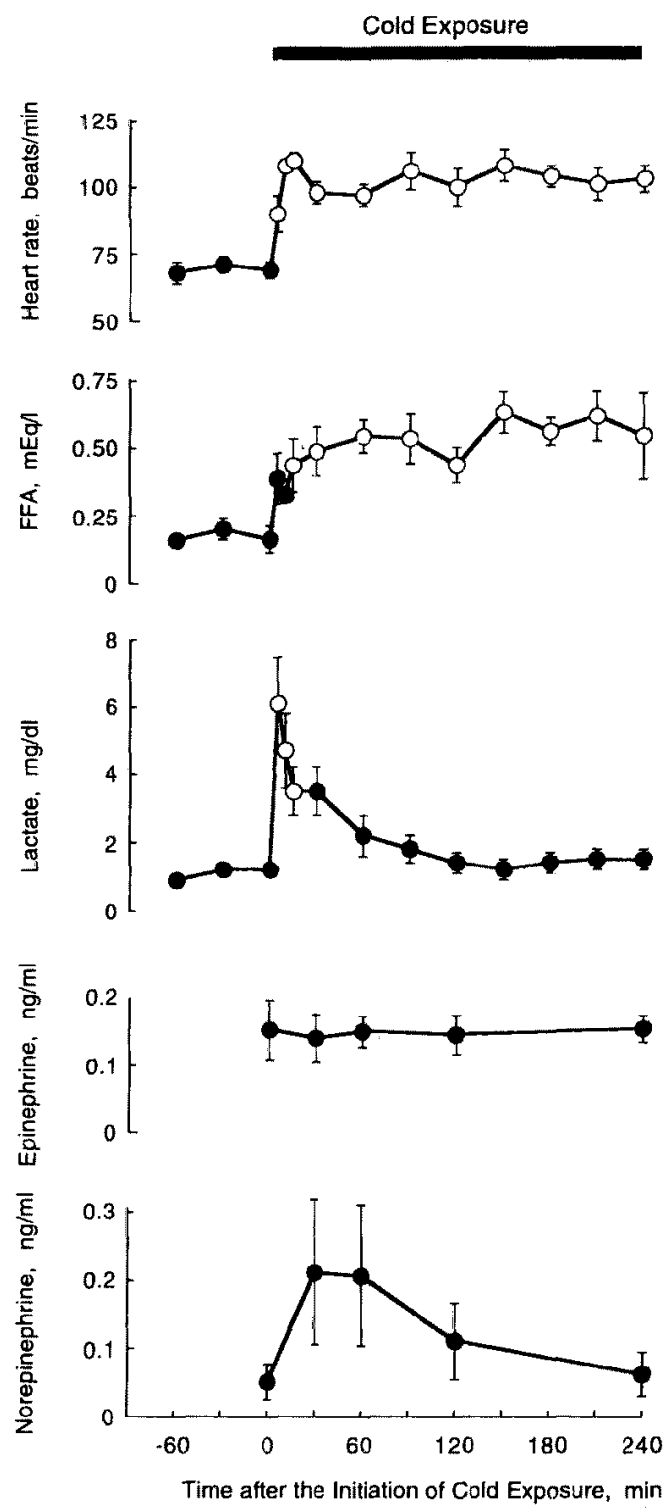

Fig. 1. The time course of heart rate, and concentrations of plasma FFA, lactate, epinephrine, and norepinephrine in sheep moved from a thermoneutral environment $\left(20^{\circ} \mathrm{C}\right)$ to a cold environment $\left(1^{\circ} \mathrm{C}\right)$ for 4 hours. Open circles indicate differences $(P<0.05)$ from the values in the thermoneutral environment. values of heart rate and plasma FFA concentration were $70 \pm 3$ beats/min and $0.17 \pm 0.03$ $\mathrm{mEq} / l$ (Fig. 1). They increased to $110 \pm 3$ beats $/ \mathrm{min}$ at $15 \mathrm{~min}(\mathrm{P}<0.01)$ and $0.63 \pm 0.08$ $\mathrm{mEq} / l$ at $150 \mathrm{~min}(\mathrm{P}<0.05)$ after the initiation of cold exposure, respectively, and were maintained at higher levels during the whole 4hours period of cold exposure. Plasma lactate concentrations increased $(\mathrm{P}<0.01)$ transiently from $1.4 \pm 0.2 \mathrm{mg} / \mathrm{d} l$ to $6.1 \pm 1.4 \mathrm{mg} / \mathrm{d} l$ at $5 \mathrm{~min}$ after the initiation of cold exposure, and returned to the thermoneutral values within 2 hours after the initiation of cold exposure. Concentrations of plasma epinephrine remained unchanged associated with the initiation of cold exposure. Although concentrations of plasma norepinephrine increased to approximately 2.8 times of the thermoneutral values at $60 \mathrm{~min}$ after the initiation of cold exposure, the changes were not statistically significant $(\mathrm{P}=0.16)$. Blood glucose concentrations increased $(P<0.05)$ after the initiation of cold exposure, but returned to the thermoneutral values at 3 hours after the initiation of cold exposure (Fig. 2). Rates of production and utilization of blood glucose were $3.9 \pm 0.2$ and $3.7 \pm 0.3 \mathrm{mg} \cdot \mathrm{kg}^{-0.75} \cdot \mathrm{min}^{-1}$ in the thermoneutral environment, respectively. They were the mean values during the $60 \mathrm{~min}$ period before the initiation of cold exposure. The production and utilization rates increased after the initiation of cold exposure, reaching $6.5 \pm$ 0.6 and $6.2 \pm 0.4 \mathrm{mg} \cdot \mathrm{kg}^{-0.75} \cdot \mathrm{min}^{-1}$ respectively at $30 \mathrm{~min}(\mathrm{P}<0.01)$, and were maintained close to these levels, higher than in the thermoneutral environment thereafter. Although no significant difference was observed between production and utilization rates during cold exposure, the elevated blood glucose concentrations were due to a greater enhancement in production rates relative to utilization rates.

\section{Discussion}

The blood glucose turnover rate, determined by isotope dilution using radioactive 
Glucose Metabolism in Acute Cold Exposure

compounds, is enhanced during cold exposure $^{1,11,15,17)}$. These data were calculated under steady state conditions. However, acute cold exposure was expected to cause rapid changes in glucose metabolism. Therefore, in this experiment the non-steady state equations

Cold Exposure
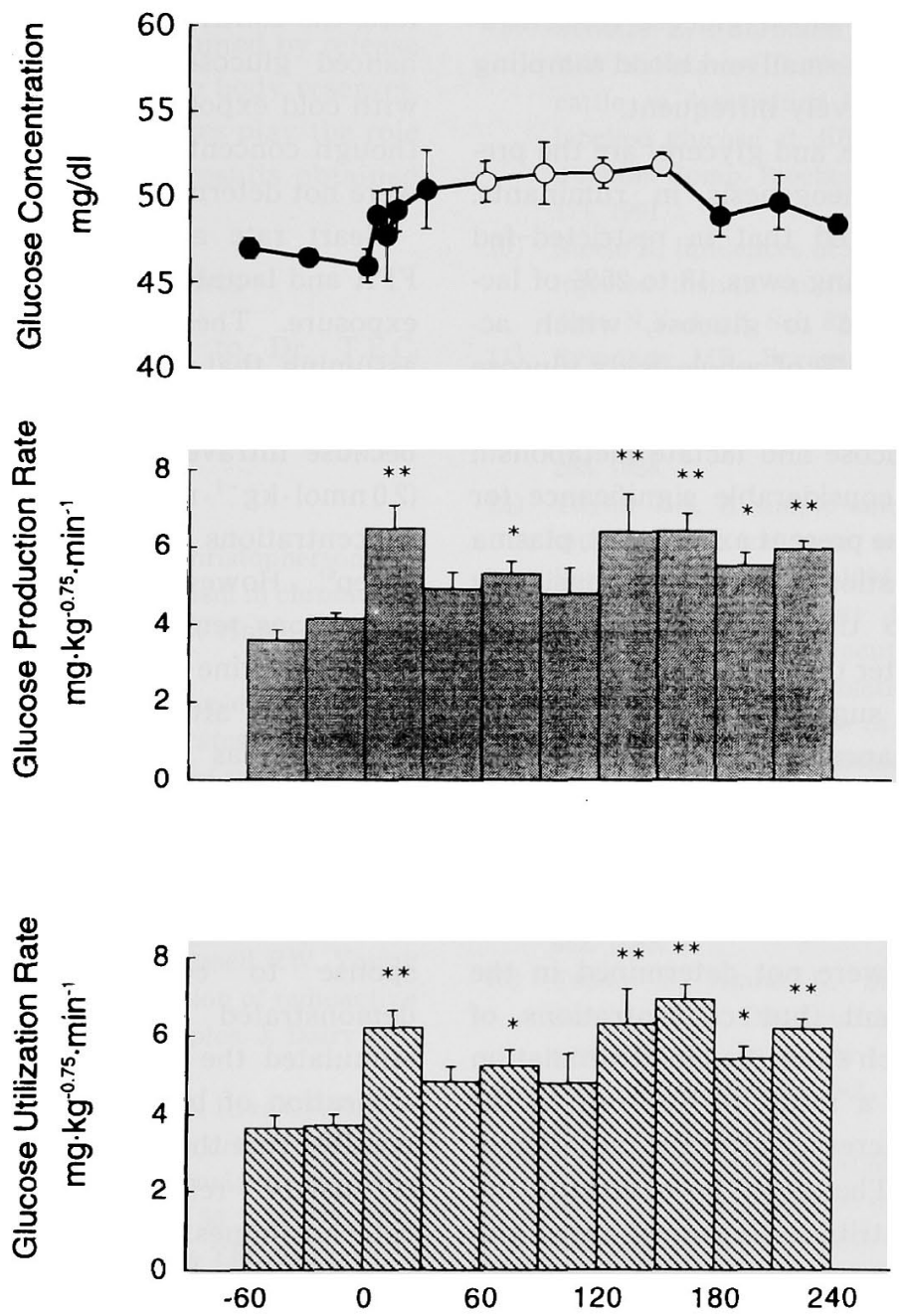

Time after the Initiation of Cold Exposure, min

Fig. 2. The time course of blood glucose concentrations, and rates of production and utilization of blood glucose in sheep moved from a thermoneutral environment $\left(20^{\circ} \mathrm{C}\right)$ to a cold environment $\left(1^{\circ} \mathrm{C}\right)$ for 4 hours. Open circles indicate differences $(\mathrm{P}<0.05)$ from the values in the thermoneutral environment for blood glucose concentrations. Asterisks indicate differences ${ }^{*}$ or ${ }^{* *} \mathrm{P}<0.05$ or 0.01 , respectively) from the values in the thermoneutral environment for blood glucose metabolism. 
proposed by Steele ${ }^{10}$, which allow for changes in the size of the blood glucose pool, were used for calculating production and utilization rates of blood glucose. Both rates increased immediately after the initiation of cold exposure, whereas no significant difference was observed between them over the period of cold exposure, because changes in blood glucose concentrations were relatively small and blood sampling intervals were relatively infrequent.

Propionate, lactate, and glycerol are the precursors for gluconeogenesis in ruminants. Perry et al. ${ }^{5)}$ reported that in restricted-fed pregnant and lactating ewes, 18 to $25 \%$ of lactate was converted to glucose, which accounted for 18 to $31 \%$ of whole-body glucose turnover rate. Therefore, the interrelationship between glucose and lactate metabolism seems to be of considerable significance for ruminants. In the present experiment, plasma lactate concentrations increased transiently and returned to the thermoneutral values within 2 hours after the initiation of cold exposure. This may suggest that glycogenolysis was initially enhanced in response to cold exposure, but did not continue for the 4 hours period of cold exposure. Moreover, the glycerol turnover rate is enhanced during cold exposure $\left(0^{\circ} \mathrm{C}\right)$ in sheep ${ }^{15}$. Concentrations of plasma glycerol were not determined in the present experiment, but concentrations of plasma FFA, which enter the blood circulation with glycerol as a result of lipolysis in the adipose tissues, increased after the initiation of cold exposure. Therefore, both lactate and glycerol may contribute to the enhanced glucose production as precursors associated with the initiation of cold exposure.

Propionate concentrations in the rumen remained unchanged while the postprandial release of propionate into the portal blood was greater in sheep acutely exposed to $\operatorname{cold}^{2.13)}$. These findings may suggest an increased contribution of propionate to glucose production during cold exposure. In this experiment, however, the sheep were exposed to a cold environment at 20-24 hours after feeding. Van der Walt ${ }^{15)}$ reported that in sheep the turnover rate of glucose derived from propionate was lower during a basal phase (8-10 hours after feeding) than during a maximum fermentation phase (2-4 hours after feeding). Therefore, the contribution of propionate to the enhanced giucose production rate associated with cold exposure was likely to be small, although concentrations of volatile fatty acids were not determined.

Heart rate and concentrations of plasma FFA and lactate increased in response to cold exposure. These responses would be expected assuming that catecholamines were secreted associated with the initiation of cold exposure, because intravenous infusion of epinephrine $\left(2.0 \mathrm{nmol} \cdot \mathrm{kg}^{-1} \cdot \mathrm{min}^{-1}\right)$ increased heart rate and concentrations of plasma FFA and lactate in sheep $^{6)}$. However, plasma epinephrine concentrations remained unchanged and plasma norepinephrine concentrations increased numerically after the initiation of cold exposure, whereas they determined at relatively longer time intervals did not change. It may be that these catecholamines were secreted transiently associated with the initiation of cold exposure rather than there being no response to cold exposure. Sano et al..$^{\text {i) }}$ demonstrated that in sheep epinephrine stimulated the rates of both production and utilization of blood glucose. Therefore, it is possible that the enhanced glucose production is partly related to the secretion of catecholamines.

In the present experiment, the sheep's metabolism cages were moved about 10 meters from the thermoneutral environment to the cold environment. Therefore, an effect of transfer could not be excluded. Parrottet al. ${ }^{4)}$ reported that in sheep epinephrine release was stimulated by transportation throughout the treatment period. Plasma epinephrine concentrations determined at $30 \mathrm{~min}$ after the 


\section{Glucose Metabolism in Acute Cold Exposure}

initiation of cold exposure were similar to the values obtained in the thermoneutral environment. Therefore, the effect of transfer might be small by $30 \mathrm{~min}$ after the initiation of cold exposure and thereafter.

In conclusion, production and utilization rates of blood glucose increased associated with the initiation cold exposure. Glucose production may partly be sustained by release of lactate and glycerol from the body reserves. It is possible that catecholamines play the role in that mobilization, but the results obtained were not clear.

\section{Acknowledgements}

The authors are grateful to Dr. T.E.C. Weekes, University of Newcastle upon Tyne, for his kind comments on the manuscript.

\section{References}

1) Early RJ, Thompson JR, Christopherson RJ. Glucose and alanine metabolism in chronically cold-exposed sheep. Can. J. Anim. Sci., 70 : 517-524. 1990.

2) Kennedy PM. Influences of cold exposure on digestion of organic matter, rates of passage of digesta in the gastrointestinal tract, and feeding and rumination behaviour in sheep given four forage diets in the chopped, or ground and pelleted form. Br. J. Nutr., $53: 159-173$. 1985.

3) Mills SE, Armentano LE, Russell RW, Young $\mathrm{JW}$. Rapid and specific isolation of radioactive glucose from biological samples. J. Dairy Sci., 64: 1719-1723. 1981.

4) Parrott RF, Misson BH, De La Riva CF. Differential stressor effects on the concentrations of cortisol, prolactin and catecholamines in the blood of sheep. Res. Vet. Sci., $56: 234-239.1994$,

5) Perry KW, Janes AN, Weekes TEC, Parker DS, Armstrong DG. Glucose and L-lactate metabolism in pregnant and in lactating ewes fed barley- or ground maize-based diets. Exp. Physiol., $79: 35-46.1994$.

6) Sano H, Fujita T, Murakami M, Shiga A. Stimulative effect of epinephrine on glucose production and utilization rates in sheep using a stable isotope. Domest. Anim. Endocrinol., 13 : 445-451. 1996.

7) SAS. SAS User's Guide : Statistics. SAS Inst., Inc., Cary, NC. 1985.

8) Sasaki Y, Weekes TEC. Metabolic responses to cold. In : Control of Digestion and Metabolism in Ruminants. (Milligan LP, GrovumWL, Dobson A eds.) 326-343. Prentice-Hall. Englewood Cliffs. 1986.

9) Schulze E, Fuhrmann H, Neitzel E-S, Giese WW, Sallmann HP. Glucose entry rate in dairy cattle as determined by stable isotope ${ }^{13} \mathrm{C}$ labelled glucose at different stages of reproduction. Comp. Biochem. Physiol., 100 B : 167171. 1991 .

10) Steele R. Influences of glucose loading and of injected insulin on hepatic glucose output. Ann. N.Y. Acad. Sci., 82 : 420-430. 1959.

11) Symonds ME, Bryant MJ, Shepherd DAL, Lomax MA. Glucose metabolism in shorn and unshorn pregnant sheep. Br. J. Nutr., $60: 249-$ 263. 1988

12) Taylor KA. A simple colorimetric assay for muranic acid and lactic acid. Appl. Biochem. Biotechnol, 56 : 49-58. 1996.

13) Thompson GE, Bassett JM, Bell AW. The effects of feeding and acute cold exposure on visceral release of volatile fatty acids, estimated hepatic uptake of propionate and release of glucose, and plasma insulin concentration in sheep. Br. J. Nutr., $39: 219-226.1978$.

14) Tserng $\mathrm{K}-\mathrm{Y}$, Kalhan SC. Estimation of glucose carbon recycling and glucose turnover with $\left[\mathrm{U}-{ }^{13} \mathrm{C}\right]$ glucose. Am. J. Physiol., $245:$ E 476-E 482. 1983.

15) Tsuda $T$, Ambo $K$, Shoji $Y$, Fujita $M$, Sunagawa K. Distribution of energy source expenditure in warm- and cold-exposed sheep. Can. J. Anim. Sci., 64 (Suppl.) : 265-266. 1984.

16) Van der Walt JG. Volatile fatty acid metabolism. 3. Diurnal variation in the contribution of ruminal propionic acid production to the whole body glucose turnover of Merino sheep fed lucerne hay twice daily. Onderstepoort $\mathrm{J}$ Vet. Res., 45 : 125-132, 1978.

17) Weekes TEC, Sasaki Y, Tsuda T. Enhanced responsiveness to insulin in sheep exposed to cold. Am. J. Physiol., 244 : E 335-E 345. 1983. 
TAKEBAYASHI, KOBAYASHI, FUJITA, SANO and SHIGA

\title{
ヒッジにおける急性寒冷暴露に対する血液グルコース代謝動態 の経時的变化
}

\author{
竹林明美・小林 薫・藤田忠久 ・佐野宏明・志賀瓏郎
}

岩手大学農学部, 盛岡市 $020-8550$

\begin{abstract}
急性寒冷暴蕗に対する血液グルコース産生速度および利用速度の経時的变化を測定するために，4頭 のヒッジを常温環境 $\left(20 \pm 1^{\circ} \mathrm{C}\right)$ から寒冷環境 $\left(1 \pm 1^{\circ} \mathrm{C}\right)$ に移動して 4 時間暴露した. 血液グルコース代 謝動態は $\left[\mathrm{U}-{ }^{19} \mathrm{C}\right]$ グルコースおよび非定常状態の計算式を用いた同位元素希釈法により測定した，血

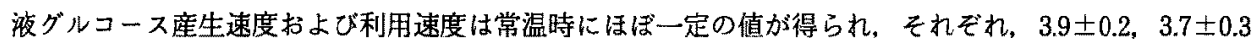
$\mathrm{mg} \cdot \mathrm{kg}^{-0.75} \cdot \mathrm{min}^{-1}$ であった．血液グルコース産生速度および利用速度はいずれる寒冷暴露に伴って增 加し, 30 分後には $6.5 \pm 0.6,6.2 \pm 0.4 \mathrm{mg} \cdot \mathrm{kg}^{-0.75} \cdot \mathrm{min}^{-1}(\mathrm{P}<0.01)$ に達し, 寒冷暴露の間常温環境の值よ りも高い値で推移した，本実験の結果より，寒冷暴露の開始に伴って血液グルコース代謝動態は直ちに 㫕進することが示された。
\end{abstract}

日畜会報, $69(8): 734-740,1998$ 